\title{
Knowledge of Elementary School Physical Education Teachers in Bantul Regency About
}

\section{Learning model}

\author{
Abdul Mahfudin Alim ${ }^{1, *}$ Sumaryanti Sumaryanti ${ }^{1,}$ Pamuji Sukoco ${ }^{1}$ \\ ${ }^{1}$ Faculty of Sport Sciences, Universitas Negeri Yogyakarta, Yogyakarta, Indonesia \\ *Corresponding author.Email: mahfudin@uny.ac.id
}

\begin{abstract}
This study aims to obtain empirical data regarding the knowledge of Elementary School Physical Education teachers about learning models in Physical Education. This research is a quantitative descriptive study using a survey method. The population in this study were elementary school physical education teachers who were members of the Teacher Working Group in Bantul Regency, Yogyakarta Special Region. The instrument used in this study was a multiple-choice test, which consisted of 30 questions using the google form. The research data were analyzed quantitatively in the form of percentages and converted into a categorical scale Based on the results of the assessment norms for the level of teacher knowledge about learning models, it shows that respondents who are in the high category are 0 respondents $(0 \%)$, respondents who are in the sufficient category are 4 respondents $(19 \%)$, respondents who are in the low category are 5 respondents $(24 \%)$, and respondents who were in the less category were 12 respondents $(57 \%)$.
\end{abstract}

Keywords: Learning models, Teachers, Physical education, Teacher working groups

\section{INTRODUCTION}

The four teacher competencies according to Law Number 14 of 2005 are pedagogic competence, personality competence, social competence, and professional competence [1]. Pedagogic competence is the skill or ability of the teacher in managing a learning process. These abilities are related to how a teacher has knowledge about learning models (instructional models). states that there are eight (8) kinds of learning models in Physical Education (Penjas). Eight models used in physical education learning include direct learning (Direct Instruction), inquiry (inquiry), pairs (Peer Teaching), tactical approaches (Tactical games), individual systems learning models (Personalized System of Instructions), Cooperative (cooperative)), personal and social responsibility model (TPSR),

From a variety of learning models, as a physical education teacher, you can use models for the implementation of learning with adjusted targets to be the main target or priority domain. In reality, learning still looks monotonous, this is as stated by
Sujarwo (2020) that $16.7 \%$ of Physical Education teachers in the learning process use a tactical approach (TGFU), 26.7\% use a psychomotor approach, and $53.3 \%$ use a drill approach [5]. This is also reinforced by the results of an interview in February 2021 by telephone with one of the Physical Education teachers who represent Bantul district with the criteria for teaching in elementary schools. What is interesting from the respondent's statement is that the learning design actually includes student-centered learning methods as emphasized in the 2013 curriculum. From the results of the interviews, it can be concluded that the selection of the learning model is still more towards the command and exercise teaching style. In addition, understanding of learning models is still lacking because they are more familiar with teaching styles. In addition, the emphasis on learning is also more towards the psychomotor and cognitive domains, while affective values still tend to be interactive domains. because it is only to fulfill the necessary administration. From the results of the interviews, it can be concluded that the selection of the learning model is still more towards the command 
and exercise teaching style. In addition, understanding of learning models is still lacking because they are more familiar with teaching styles. In addition, the emphasis on learning is also more towards the psychomotor and cognitive domains, while affective values still tend to be interactive domains. because it is only to fulfill the necessary administration. From the results of the interviews, it can be concluded that the selection of the learning model is still more towards the command and exercise teaching style. In addition, understanding of learning models is still lacking because they are more familiar with teaching styles. In addition, the emphasis on learning is also more towards the psychomotor and cognitive domains, while affective values still tend to be interactive domains.

Physical Education Teachers broaden the concept of methods to include several innovative teaching strategies and teaching styles, the last of which are set out in Muska Mosston's Teaching Style Spectrum [2][3][4]. Mosston has identified that in his teaching the way teachers can be distinguished from how teachers treat and involve students in learning. The way the teacher involves students is finally commonly called the teaching style.

In its development, the teaching style then evolved more towards a learning model. A physical education teacher is required to master various strategies in teaching. This is based on the fact that in physical education there are various conditions that must be taken into account, especially regarding the conditions of students who vary greatly in the three priority domains of learning, both cognitive, affective and psychomotor, so it would be impossible if the teacher only used one model in teaching in teaching and learning. a period of learning. In addition, a teacher must also be able to determine the appropriate learning model to use, including how to involve students in the learning process to achieve the goals that have been set. Teachers can design the course of learning with different formats, From the background, it is hoped that a Physical Education teacher has knowledge of the instructional model in Physical Education and there is no empirical data regarding the knowledge of Elementary School Physical Education teachers in Bantul Regency about the learning model. Therefore, a survey on the knowledge of Physical Education teachers is needed that focuses on the Physical Education learning model.

\section{METHODS}

\subsection{Material}

A theoretical foundation in the instructional model instruction is the desired learning outcomes. In addition, a physical education teacher must have knowledge of the content or content. The process of learning activities must be in accordance with student development and sequentially. There are expectations for good behavior from teachers and students. The learning model has a unique task structure. As well as the assessment of learning outcomes that refer to benchmarks to assess the implementation of the models used. [2] [3] [4] [5] [6] [7] [8]

There are eight learning models in Physical Education that are often used. The lessons are [2] [3] [4]: (1) Direct Learning (Direct Instruction), (2) Inquiry (inquiry), (3) in pairs (Peer Teaching), (4) Tactical approach (Tactical games), (5) Individual system learning model (Personalized System of Instructions), (6) cooperative (cooperative), (7) Personal and social responsibility model (TPSR), and (8) Event-based learning model (Sport Education).

\subsection{Research Design}

This research is a quantitative descriptive study using a survey method. The research data were analyzed quantitatively in the form of percentages and converted into a categorical scale.

\subsection{Sampling and Data Collection}

The population of the study on the level of knowledge of Physical Education teachers regarding the learning model that we carried out were Physical Education teachers who were members of the Physical Education KKG in Bantul Regency totaling 21 teachers. Temporary The sampling technique used is total sampling who are willing to fill out the survey. The instrument used in this study was a multiple choice test which consisted of 30 questions using the google form.

\subsection{Data Analysis}

Data from surveys that have been collected inquantitatively analyzed with SPSS v28 software then poured in the form of a percentage and converted into a category scale. 
Table 1. Deskriptive statistics of teacher knowledge about physical education learning models in the physical education teacher working group in Bantul regency

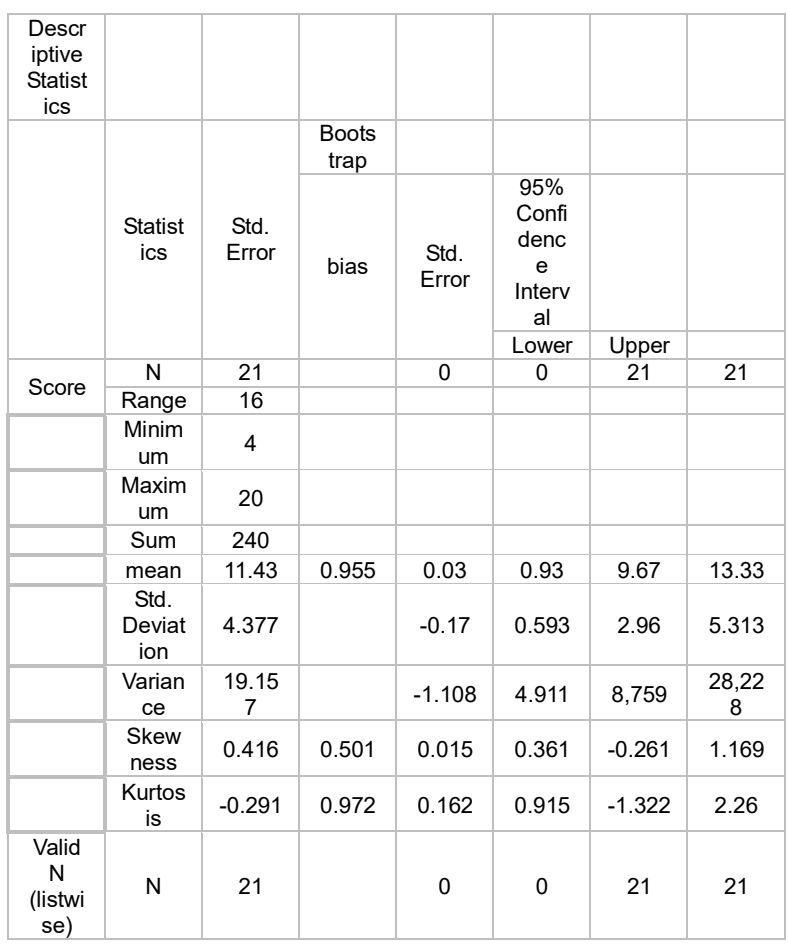

Table 2. Norms of assessment of the teacher knowledge levels about physical education learning models in the physical education teacher working group in Bantul regency

\begin{tabular}{|c|l|l|c|c|}
\hline No & interval & $\begin{array}{c}\text { Catego } \\
\text { ry }\end{array}$ & $\begin{array}{c}\text { Freque } \\
\text { ncy }\end{array}$ & $\%$ \\
\hline 1 & $\begin{array}{l}76 \%-1 \\
00 \%\end{array}$ & Tall & 0 & 0 \\
\hline 2 & $\begin{array}{l}56 \%-7 \\
5 \%\end{array}$ & $\begin{array}{l}\text { Enoug } \\
\text { h }\end{array}$ & 4 & $19 \%$ \\
\hline 3 & $\begin{array}{l}40 \%-5 \\
5 \%\end{array}$ & Low & 5 & $24 \%$ \\
\hline 4 & $\begin{array}{l}<40 \% \\
\text { Amount }\end{array}$ & $\begin{array}{l}\text { Not } \\
\text { enoug } \\
\text { h }\end{array}$ & 12 & $57 \%$ \\
\hline & 21 & $100 \%$ & & \\
\hline
\end{tabular}

\section{DISCUSSION}

The survey was carried out using a multiple choice test containing 30 questions with 21 respondents who were members of the Physical Education KKG in Bantul Regency with analysis using SPSS v.28 software showing the lowest score of 4 and the highest score of 20 and an average score of 11.43. Based on the norm of assessing the level of teacher knowledge about learning models incorporated in the Physical Education KKG in Bantul Regency (Table 1), it shows that respondents who are in the high category are 0 respondents $(0 \%)$, respondents who are in the sufficient category are 4 respondents $(19 \%)$, respondents who were in the low category were 5 respondents (24\%), and respondents who were in the less category were 12 respondents (57\%).

\section{CONCLUSION}

The results of the study indicate that the level of knowledge of Physical Education teachers who are members of the Physical Education KKG in Bantul Regency regarding learning models needs to be improved. Researcher recommend to related parties to be able to provide training professional development programs and researchers can conduct training through community service activities in the form of seminars or workshops.

\section{ACKNOWLEDGMENT}

We would like to express our deepest gratitude to our research respondents who have responded well and filled out the knowledge test in this study. Thank you to KKG Penjas in Bantul Regency for allowing us to conduct this research so that this research can be carried out by providing useful information.

\section{REFERENCES}

1. Law Number 14 of 2005 concerning Teachers and Lecturers

2. Metzler, M. (2011). Instructional Models in Physical Education (3rd ed.). Routledge.https://doi.org/10.4324/97813152135 21

3. Metzler, M. (2017). Instructional models for physical education (3nd ed.). USA: Routledge

4. Casey, A., \& MacPhail, A. (2018). Adopting a models-based approach to teaching physical education. Physical Education and Sport Pedagogy, 23(3), 294-310. doi:10.1080/17408989.2018.1429

5. Sujarwo. (2020).Development of Physical Education Learning Model Material for Mini Volleyball Game to Habituate Character Values of Elementary School Students. Dissertation, unpublished, Yogyakarta State University, Yogyakarta.

6. Backman, E., \& Barker, DM (2020). re-thinkg pedagogical content knowledge for physical education teachers - implications for physical education teacher education. Physical Education 
and Sport Pedagogy, 1-13. doi:10.1080/17408989.2020.1734

7. Ní Chróinín, D., Fletcher, T., \& O'Sullivan, M. (2017).Pedagogical principles of learning to teach meaningful physical education. Physical Education and Sport Pedagogy, 23(2), 117-133. doi:10.1080/17408989.2017.1342789

8. Lavay, Barry . French, Ron \& Henderson, Hester. (2016). Positive Behavior Management in Physical Activity Settings. (2nd ed.). United States: Human Kinetics, Champaign, IL. 